\title{
Policy Network: Smart Village Program in Banyuwangi Regency
}

\author{
Dewi Gartika1, Budiman Rusli' ${ }^{2}$, Atik Rochaeni ${ }^{3}$, Riki Satia Muharam ${ }^{4}$ \\ ${ }^{1}$ Researcher at BP2D West Java Province (email : d_gartika@yahoo.com), ${ }^{2}$ Departement of Public Administration \\ \& Center for Public Policy and Public Service Studies, Faculty of Social and Political Sciences, Universitas \\ Padjadjaran (email : budiman9560@gmail.com), ${ }^{3}$ Departement of Public Administration, Universitas Nurtanio \\ (email : fisip@unnur.ac.id), ${ }^{4}$ Doctoral Candidate in Public Administration at Universitas Padjadjaran \& \\ Researcher at Center for Public Policy and Public Service Studies, Universitas Padjadjaran; Lecturer at STIA \\ CIMAHI (email : riki.satiam@gmail.com)
}

\begin{abstract}
Smart Kampung is a concept of community development in a community to do something smart / wise in overcoming various problems with the ability of resources that are available efficiently in an area. Smart village aims to encourage the development of rural areas by integrating development of productive economic activities, creative and socio-cultural activities, improving public services, improving the quality of education, improving the quality of health services and alleviating poverty by utilizing the use of information and communication technology. Constraints that occur in smart village program from the network with limited quota and lack of human resources for service operators. This study aims to examine and analyze related policy networks in the implementation of the Smart Village program in Banyuwangi Regency. The theory used in this research is the Policy Network theory from Frans Van Waarden. The method used is a qualitative research method. The results of the study show that the actors involved in the implementation of the Smart Kampung program consisted of government and community elements. Research recommendations on the need for other actors involved in implementing smart village programs such as the social community, the private sector and academics.
\end{abstract}

\section{Keywords:}

policy; network; smart village; Banyuwangi

\section{Introduction}

Banyuwangi Regency is the largest regency in East Java Province. The land area of Banyuwangi Regency reaches 5,782.50 km2 and has a coastline of around $175.8 \mathrm{~km}$ and 10 islands, which are divided into 24 sub-districts, 189 villages and 28 villages. The furthest village distance from the Banyuwangi Regency capital is approximately $200 \mathrm{~km}$ and takes about 3 hours. This shows how wide the area of Banyuwangi Regency. On the other hand, the population density of Banyuwangi Regency is increasing every year. In 2013, the population density reached 272 people / km2, with the highest density being in Banyuwangi District which was 3,561 people / km2 (BPS, 2016). And in 2018, the population density of 
Banyuwangi Regency will increase to 278 inhabitants / km2, with the highest density being found in Banyuwangi District which is 3,661 inhabitants / km2 (BPS, 2019). Long distance and uneven population density become one of the obstacles for the Banyuwangi Regency Government to provide basic services and public services to its people optimally.

Seeing these conditions, the Banyuwangi Regency Government will certainly face various problems and challenges. Banyuwangi Regency's RPJMD in 2016-2021 states there are 15 strategic development issues in Banyuwangi Regency, namely (1). Lack of community access to basic quality needs; (2) Not yet optimal strengthening of social capital and PMKS handling; (3) MSME bargaining position is not yet strong and entrepreneurial resources; (4) Economic growth that has not focused on the superior sector; (5) Income and infrastructure disparities that still need to be resolved; (6) Not optimal tourism contribution to GRDP; (7) Inadequate provision of public facilities and supporting infrastructure for the economy; (8) Low access of the people to clean water and a healthy and quality environment; (9) Not yet developed the disaster management system; (10) Good quality spatial planning but not yet accompanied by proportional public green space rates; (11) Low human resource capacity in rural areas; (12) Increased affirmation of the protection of women and children and gender equality; (13) Not optimal efforts to prevent environmental pollution and natural resources; (14) Government administration is not yet optimal; and (1\%) Effective, efficient and information technology based public services are not yet in operation.

The above problems arise as a result of suboptimal performance of government services. The low access of the public to access to basic services and public services is a result of the lack of government services to the community. With such a large district area and limited APBD capability, it certainly becomes an obstacle in the development of basic service infrastructure and public services. To that end, the Banyuwangi Regency Government must strive to find the right solution so that basic infrastructure and public service needs can be met without burdening the APBD. The provision of an effective and efficient public service infrastructure based on Information Technology is a policy choice implemented by the Banyuwangi Regency Government. The development and utilization of Information Technology has become one of the Strategic Programs for Infrastructure Development in Banyuwangi Regency, besides the development of other infrastructure such as road 
networks, bridges, irrigation, and others. The program will mainly be built in 189 villages and 28 villages which are the spearhead of government services.

However, the implementation of the Information Technology development and utilization program also faces obstacles. Stakeholder involvement becomes very important. The implementation of the Smart Village Program involves Local Government, Private and Community, this is in line with the theory from Etzkowitz that in networking involves 1) Business, 2) Government, 3) Community, 4) Academic, 5) Media. When looking at the problems found in the Policy Network, the Government is too dominant while the role of the public is less visible. So the problem of the implementation of the Smart Village Program arises due to ineffective Policy Networks, even though Policy Networking plays an important role.

The use of Frans Van Waarden's theory (in Hidayat \& Susanti, 2015) as the basis, direction, and guidance in research on the Policy Network in the Management of Smart Village, as a media in compiling research, harmonizing and harmonizing and also explaining the values and objectives to be achieved in research.

Contextually, Frans Van Waarden's theory (in Hidayat \& Susanti, 2015) relates to what is being studied, in accordance with its context, with regard to the Policy Network in the implementation of the Smart Village Program in Banyuwangi Regency in terms of aspects: 1) Actors (actors) ), 2) Function (function), 3) Structure, 4) Institutionalization (institutionalization), 5) Rules of conduct, 6) Power relations, 7) Actor strategies .

Based on the description above, the research discusses the Policy Network in the implementation of the Smart Village Program in Banyuwangi Regency, so the research question can be raised as follows "How is the Policy Network in the implementation of the Smart Village Program in Banyuwangi Regency?"

\section{Methods}

This research is intended to find out "How is the Policy Network in the implementation of the Smart Village Program in Banyuwangi Regency?". Therefore, the research method used is a qualitative method. The qualitative research method was chosen by the researcher with the consideration that: first, the belief that truth can be more achieved by using qualitative methods, this is in line with the opinion of Bogdan and Taylor (1992: 18- 
22) that : "... Through qualitative methods we can get to know people (subjects) personally and see them develop their own definition of this world, we can feel what they are experiencing in their daily struggles, can study groups and experiences that we may not know at all. And finally, qualitative methods allow us to investigate concepts that in other research approaches, the essence will be lost.

\section{Results and Discussion}

Banyuwangi Regency is located at the east end of Java Island with coordinates of $7^{\circ}$ $43^{\prime}-8^{\circ} 46^{\prime}$ LS and $113^{\circ} 53^{\prime}-114^{\circ} 38^{\prime}$ BT. The land area consists of highlands in the form of mountains which are producing regions of agricultural products, and lowlands with a variety of potential agricultural products as well as areas around the coastline along the $175.8 \mathrm{~km}$ stretching from north to south which are producing various marine biota. Banyuwangi Regency has an area of 5,782.50 km2 which is a forest area. The area of this forest area reaches $183,396.34$ ha or about $31.72 \%$, rice fields around 66,152 ha or $11.44 \%$, plantations with an area of about $82,143.63$ ha or $14.21 \%$, settlements with an area of about $127,454.22$ ha or $22,04 \%$, and the rest is used for roads, fields and others. Banyuwangi Regency also has 10 islands.

Banyuwangi Regency consists of 25 sub-districts, 28 sub-districts and 189 villages, 87 neighborhoods and 751 hamlets, 2,839 neighborhood units (RW) and 10,569 neighborhood units (RT). In 2018 the population of Banyuwangi Regency was 1,735,845, consisting of 864,124 women and 871,721 men, with a sex ratio of $100.9 \%$. The population is spread over 25 Subdistricts, namely Pesanggaran, Bangorejo, Purwoharjo, Tegaldlimo, Muncar, Cluring, Gambiran, Srono, Genteng, Glenmore, Kalibaru, Singojuruh, Rogojampi, Kabat, Glagah, Banyuwangi, Giri, Wongsorjo, Songgon, Genteng, Glenmore, Kalibaru, Singojuruh, Rogojampi, Kabat, Glagah, Banyuwangi, Giri, Wongsorjo, Songgon, Sempu, Kalipuro, Silipurai, Silipuroro, Silipuroro, Tegalsari, Licin and Baru District, Blimbingsari District.

Banyuwangi Regency is classified as an area that is not yet densely populated. Population density in Banyuwangi Regency in 2018 is 300.19 people / km². In other words, an average of every km2 in Banyuwangi Regency is inhabited by 300 people in 2018. 
Policy Network in the implementation of the Smart Village Program in Banyuwangi Regency, according to Frans Van Waarden, the policy network model consists of several dimensions, namely: 1) Actors, 2) Function, 3) Structure, 4) Institutionalization (institutionalization) ), 5) Rules of conduct, 6) Power relations, 7) Actor strategies.

\section{Actors}

In formulating policies, actors relate to the number of people involved (participants). This factor then determines the size of the network to be built. Furthermore, the characteristics of the policy network will be influenced by different types of actors from the background. Actors in the policy network are individuals but can also be an organization as the actors involved can also be representations of certain groups / parties.

In order to ensure the continued implementation of the Smart Village Program in villages, the actors are related to the implementation of the Smart Village Program in Banyuwangi Regency, namely: First, the Indramayu Regency Government consists of Regional Apparatuses, Sub-districts / Kelurahan, and Village Governments; Second, the Village Community; Third, PT Telkom.

\section{Function \& Structure}

Network is a communication media that manifests in several functions. Its functions depend on the needs, intentions, resources, and strategies of the actors involved. The concept of "function" then forms the connecting perspective between the structure and the actors in the network. The main function of network policy is as a tool used to increase the intensity of relationships between parties concerned with a public policy both at the formulation and implementation stages. The structure of the policy network refers to the pattern of relationships between the actors involved.

In order to ensure the continued implementation of the Smart Village Program in villages, the Banyuwangi Regency Government has mapped the roles and functions of each stakeholder, namely: First, the Indramayu Regency Government: a) Regional Apparatus. The Regional Apparatus involved in the Smart Village Program must draw up a plan and allocate its activity budget to support the Smart Village Program in accordance with the tasks and principal of each regional apparatus. Each program that is compiled must synergize with other regional government programs, so that it will increase the efficiency and effectiveness of program performance; b) District / Kelurahan. The Kecamatan / 
Kelurahan work program must also support the programs and activities of the regional apparatus that are summarized in the Smart Village Program. The Camat must begin to increase the capacity and competence of its devices to be able to work together in the Smart Village Program. In addition, the Camat must also be able to provide guidance to the Lurahs and Villages to be able to optimally utilize the Smart Village Program to improve the quality of services and economic growth in his village. Village government; c) Village Government. In Banyuwangi Regent Regulation Number 18 Year 2016 it is explained that in order to increase synergy between the district government and the village government, funding for the implementation of the Smart Kampung program can be charged to the Banyuwangi Regency Regional Budget and Expenditure (APBD), and / or the Village Budget APBDes). The Minister of Villages, Disadvantaged Regions and Transmigration has arranged that one of the budget items that can be spent from the Village Fund is infrastructure spending. Information Technology is one of the infrastructure that is needed by villages in Banyuwangi Regency to improve the quality of its services. Therefore, the Banyuwangi Regent ordered the Village Head to allocate in his Village APB for internet bandwidth purchases in his village, attend Information Technology training, provide salaries for operators, and others. On the other hand, with the criteria that must be met by the village in order to get financial assistance from the District APBD through the Smart Village Program, the village government must be able to provide adequate halls or rooms, furniture (tables, chairs, cabinets, etc.) ), sound system, LCD projector, notice / information board, play and learning facilities for children, electricity; clean water and sanitation, clean toilets, rubbish bins, print media (newspapers, magazines, etc.), greening and village libraries. This infrastructure is needed to support the synergy between regional government programs and village programs.

Second, the Village Community. As explained earlier, the Smart Kampung Program is a concept of community development in a community to do something smart / smart / wise in overcoming various problems with the ability of available resources while paying attention to the order of life and local customs and the norms that apply therein. This means that the success of this program can be measured by the independence of the village community in overcoming the problems in their villages and using all the infrastructure that has been provided by the government to meet the needs for basic services and public 
services and to develop the economy in their villages according to the potential of their villages. For example, Tamansari Village encourages residents of their villages who have houses large enough, healthy and neat to be used as homestays for tourists. The concept of the homestay must be under the supervision of the Village Head, starting from the determination of the homestay criteria that must be met by the owner, management must be done professionally, and the village government will facilitate its marketing through the digital market of banyuwangi-mall.com or its village web site.

Third, PT Telkom. PT Telkom has a role in providing towers to maintain telecommunications network connections in the villages.

\section{Institutionalization.}

The degree of institutionalization refers to the formal characteristics of the network and its stability. This will depend on the shape / characteristics of the network structure and the higher the level of institutionalization of a network, the more effective the policy network will be.

To further optimize the performance of the Smart Village Program, the Banyuwangi District Government and the village government can work together with other parties. For example, to increase the use of Appropriate Technology in the processing of natural resources in the village, the village community can be assisted by academics. With the existence of Information Technology the community can self-taught themselves learn an Appropriate Technology. However, if accompanied by academics / technology researchers, the quality of technology produced by rural communities will be better. Another example, for marketing village products, villagers can be accompanied by academics from the field of design and marketing so that their products have high selling points. Industry can be involved among others through channeling CSR funds, and others.

\section{Rules of conduct \& Power relations.}

The network is then formed by habits or rules (rules of the game) in the interactions that govern the exchange (exchange) in a network. This is sourced from the role perception, attitudes, interests, and social and intellectual-educational background of the actors involved. 
One of the main characteristics of a policy network is power relations which can be understood through observing the distribution of power. This process is in the form of a function of the distribution of resources (resources) and needs (needs) between actors and between organizational structures when involved is the organization.

To ensure the continued implementation of the Smart Kampung program in Banyuwangi District, the Banyuwangi District Head issued Banyuwangi District Regulations Number 18 of 2016 concerning the Integration of Village / Village-Based Work Programs Through Smart Kampung. In the regulation explained that what is meant by Smart Village is the concept of community development in a community to do something smart / smart / wise in overcoming various problems with the ability of available resources while paying attention to the order of life and local customs and norms that are applies therein.

Banyuwangi Regent Regulation Number 18 Year 2016 is an effort to improve the synergy and integration of programs implemented by various regional agencies, where the work locus is village or kelurahan, so that it can be carried out effectively, efficiently, and on target, and increase the participation of village and community officials villages in the implementation of the government program. This is explained in article 2 which explains that this regulation was established with the aim of: As a guideline for integrating the preparation of an integrated district government work plan; Synergize the work program of each SKPD so that it can be implemented effectively, efficiently and on target; Improving the function of village government in supporting the implementation of district government work programs; Improving the function of services to the community so that it can be directly enjoyed by the lowest strata of society; Increasing community participation and participation in the implementation of district government work programs; Make it easy for the community to get integrated services.

The scope of the district government's work program is prioritized on: public services, economic empowerment, health, poverty, legal information, education, arts and culture, and human resource capacity building.

However, the scope can be adjusted to the needs and developments so as not to limit the implementation of the work program of the district government through Smart Village. The village / kelurahan government can make a program of activities according to the socio- 
cultural conditions of the community, for example in the Field of Sports, customs, religion and other activities. To increase the synergy between the district and village governments, funding for the implementation of the Smart Kampung program can be charged to the Banyuwangi Regency Regional Budget and Expenditure Budget and / or the Village Budget and Revenue (APBDes) (Banyuwangi Regent Regulation Number 18 Year 2016 ).

\section{Actor strategies.}

In policy networks, actors use networks as strategies to manage their interdependence. They create and / or use networks to obtain their needs, interests and goals.

The parties involved in the Smart Kampung Program are limited to the district government, village government, village communities and PT Telkom. While other parties have not been involved in the program. ITB's Smart City \& Community Innovation Center (2018) in its research explained that villages in Indonesia have their own unique characteristics and different problems. Economic problems are still an obstacle for the achievement of Smart Village. To overcome this problem, village development must be done smartly. The smart solution in question is to implement a smart village, which is an ecosystem that allows the government, industry, academia and community elements to be involved to make the village better. In the smart village concept, the concept is better measured by looking at the performance of resource management so that it becomes more efficient, sustainable and involves various elements of the community. The Smart Village concept is needed so that the villages are able to find out the problems in it (sensing), understand the condition of the problem (understanding), and be able to control various existing resources to be used effectively and efficiently with the aim of maximizing services to its citizens.

\section{Conclusion}

Based on the analysis, there are seven factors that determine the Policy Network in the implementation of the Smart Village Program in Banyuwangi Regency, namely: 1) Actors, 2) Function, 3) Structure, 4) Institutionalization (institutionalization), 5) Rules of conduct, 6) Power relations, 7) Actor strategies. 
Recommendations from the results of the research analysis are as follows: 1) Cooperation with the private sector in the implementation of the Smart Village Program in Banyuwangi Regency to encourage the implementation of the Smart Village Program in Banyuwangi Regency can be more effective; 2) Adding education provided to the community in an effort to implement the Smart Village Program in Banyuwangi Regency is more effective; 3) Strengthening more intense socialization in the implementation of the Smart Village Program in Banyuwangi Regency.

\section{References}

Albrechts, Louis and Mandelbaum, Seymour. 2005. The Network Society: A New Context for Planning. New York: Routledge.

Bevir, Mark. 2011. Managing Networks: Propositions on What Managers Do and Why They Do It. Public Administration Review.

Creswell, John W. 2009. Research Design: Qualitative, Quantitative and Mixed Methods Approaches. London: SAGE Publications.

Hidayat, Andi Rahmat Dan Susanti, Gita. 2015. Model Jaringan Kebijakan Publik ～(Perumusan Kebijakan Masyarakat Adat Ammatoa Kajang Di Kabupaten Bulukumba). Makasar: Jurnal Jurusan Administrasi Pembangunan, Vol. 1: 5-10.

Kenis, Patrick and Volker Schreider. 1991. Policy Networks and Policy Analysis: Scrutinizing a New Analytical Toolbox. Policy Networks. Empirical Evidence and Theoretical Considerations, edited by Bernd Marin and Renate Maynz. Boulder / Colorado, Frankfrut: Campus Verlag / Westview Press.

Milles, Mathew B. and A. Michael Huberman. 1992. Qualitative Data Analysis. United State Of America: Sage Publications Inc.

Moleong, L. J. 2007. Metode Penelitian Kualitatif. Remaja Rosdakarya.

Sawitri, Sri. 2011. Jejaring Kebijakan Publik: Kerangka Baru Penyelenggaraan Pemerintahan. Purwokerto: Universitas Diponogoro. 